


\section{VALIDATION OF DAYLIGHT PREDICTION WITH CEL-1}
S. Treado
C. Francisco
D. Holland

U.S. DEPARTMENT OF COMMERCE

National Bureau of Standards

National Engineering Laboratory

Center for Building Technology

Gaithersburg, MD 20899

December 1984

Prepared for:

Naval Civil Engineering Laboratory

Port Hueneme, CA 93043

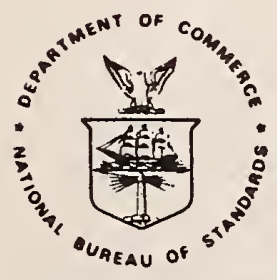

U.S. DEPARTMENT OF COMMERCE, Malcolm Baldrige, Secretary NATIONAL BUREAU OF STANDARDS, Ernest Ambler, Director 



\section{FOREWORD}

This report documents the results of National Bureau of Standards (NBS) research in support of the Naval Civil Engineering Laboratory. The report summarizes work conducted during the period January 1983 through January 1984.

We wish to acknowledge the helpful interest and guidance of the sponsor's Project Officer, Mr. William Pierpoint.

\section{DISCLAIMER}

Certain commercial equipment, instruments, or materials are identified in this report to specify the experimental procedure. Such identification does not imply recommendation or endorsement by the National Bureau of Standards nor does it imply that the materials or equipment identified are necessarily the best avallable for the purpose.

\section{ACKNOWLEDGMENTS}

The authors wish to acknowledge the efforts of all those who participated in this project and who provided insightful comments during the review process. 



\section{ABSTRACT}

Calculations of interior illuminance levels using the CEL-1 computer program are compared to measurements, for a typical office space. The comparisons are made for a wide range of sky conditions, solar intensities and seasonal intervals using a north facing window. The statistical uncertainty associated with the interior daylight calculations is examined and the sources of the uncertainty are discussed. The results show that for all sky types, the interior 11 luminance calculations have an uncertainty of $+/-24 \%$, with the major uncertainties being due to unique and unpredictable sky luminance distributions and difficulty in determining the appropriate sky condition from standard weather data.

Keywords: building energy, daylight, illuminance, fenestration, solar radiation, window 
TABLE OE CONTENTS

Page

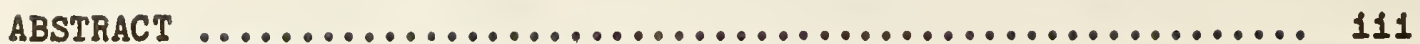

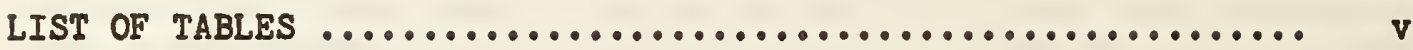

LIST OF FIGURES ................................. v1

1. INTRODUCTION $\ldots \ldots \ldots \ldots \ldots \ldots \ldots \ldots \ldots \ldots \ldots \ldots \ldots \ldots \ldots \ldots \ldots \ldots \ldots$

2. THE CEL-1 LIGHTING COMPUTER PROGRAM ................. 2

3. DESCRIPTION OF THE MEASUREMENTS ................... 4

4. RESULTS ......................................... 5

5. CONCLUSIONS $\ldots \ldots \ldots \ldots \ldots \ldots \ldots \ldots \ldots \ldots \ldots \ldots \ldots \ldots \ldots \ldots \ldots \ldots \ldots$

6. REFERENCES ................................. 8 


\section{LIST OF TABLES}

Page

Table 1. CEL-1 Input File Listing $\ldots \ldots \ldots \ldots \ldots \ldots \ldots \ldots \ldots \ldots \ldots$

Table 2. Test Room Dimensions and Reflectances $\ldots \ldots \ldots \ldots \ldots . . . .4$ 
Figure 1. Layout of Test Room ....................... g

Figure 2. Graph of CEL-1 Results vs Measured Data For Julian

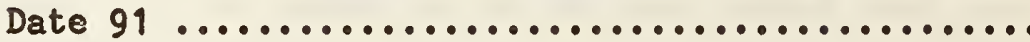

Figure 3. Graph of CEL-1 Results vs Measured Data For Julian

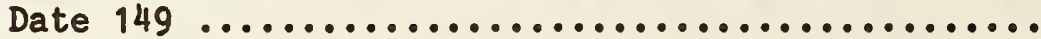

Figure 4. Graph of CEL-1 Results vs Measured Data For Julian

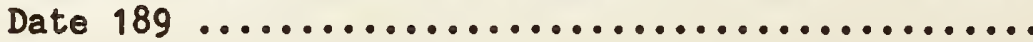

Figure 5. Graph of CEL-1 Results vs Measured Data For Julian

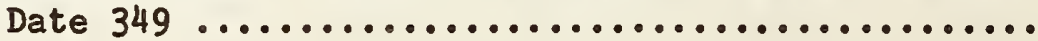

Figure 6. Graph of CEL-1 Results vs Measured Data For Julian

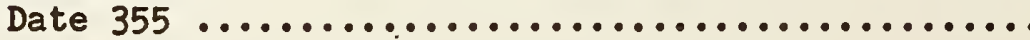

Figure 7. Scatter Plot of Measured Data vs CEL-1 Calculated Results ..............................

Figure 8. Effect of Sky Luminance Variations on Interior Illumination 


\section{INTRODUCTION}

Electrical energy for interior lighting is a significant portion of building total energy requirements, and also a large component of the cooling load $[1,2,3]$. Many studies have shown that the effective use of fenestration to provide daylight for interior spaces can be beneficial in reducing annual total building energy requirements by reducing both lighting and cooling energy use $[4,5,6,7,8]$.

When a building is being designed, the solar, thermal and daylighting impacts of various fenestration designs must be evaluated to determine the net energy impact of each design. In this manner, the optimum design may be determined and specified. The evaluation can consist of the application of various design procedures and guidelines, ranging from hand calculation procedures, to design nomographs, to detailed computer simulations. One of the critical aspects of any evaluation of fenestration performance is the prediction of interior illuminance levels due to daylight. Such a prediction is needed in order to determine the level of electric lighting required to maintain the desired interior 11 luminance. Additional calculations are required to determine the electric power required by the lighting system to provide the difference between the daylight illumination and the minimum desired il luminance level.

The purpose of this report is to validate the interior daylight prediction portion of the CEL-1 Lighting Computer Program. This program was developed by the Naval Civil Engineering Laboratory and possesses the capabilities to calculate interior lliuminance for all sky types and to model actual lighting systems, including luminaires and dimming controls. Comparison data for the validation were obtained from measurements at the NBS Daylight Research Facility, using a fullsize test room with a north-facing, unobstructed window. The test room was modeled and daylight levels calculated using CEL-1 and the results compared to the measured 11 luminance levels for a variety of sky conditions. 


\section{THE CEL-1 LIGHTING COMPUTER PROGRAM}

The test room was modeled using the CEL-1 computer simulation procedure. Detalis of developing a CEL-1 input file and executing the program can be found in other publications $[9,10]$. Basically, the test room layout, dimensions, and surface reflectances are modeled, and weather data is used to generate a model of sky and solar 1lluminace. Flux exchange calculations then are used, after each room surface is subdivided into small surfaces, to determine interior il luminance at the point of interest.

In its normal mode of operation, CEL-1 reads solar radiation data, direct and diffuse, from a weather tape. This irradiance data is translated into illuminance data which, along with the current solar angles, are required for the interior 11 luminance calculations. For the validation, the measured irradiance levels were used to drive the CEL-1 predictions, so that the predictions could be compared to the measured illuminance levels.

The CEL-1 input file listing is given in Table 1. 


\section{CEL-1 Input File Listing}

FOOM

C1:1...... 1. TE:ST Hus

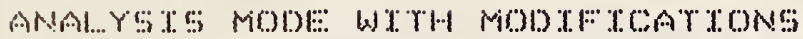

WH: ATHE BATA TNDUT

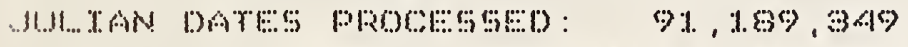

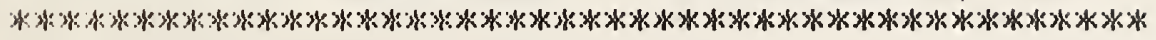

1.

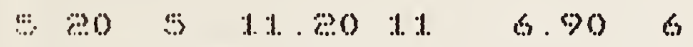

rasis

$.470 \quad .470 \quad .470 \quad .970 \quad .300 \quad .830$

rimown

A)

2..8 . 80

..00 0.00 0.0

3.600 .8000

$3.00 \quad 7.40 \quad 0.0$

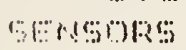

$3.60 \quad 7.40 \quad 0.0$

I.

b)

$260 \quad 9.60$ a. 606

MENETRAT TON

(.) Tr. Tow

1. .800

3. 30 a.80

1.

त. 0.00 1. 1.000

BuTH... TW:

I.

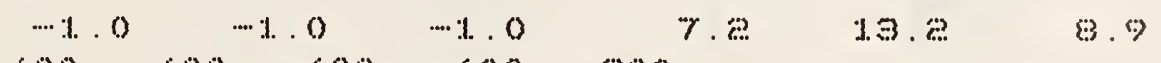

$.600 \quad .600 \quad .600 \quad .600 \quad .600$

0.0

mINOSNE

.800

0

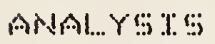

$38.50 \quad 77.00 \quad 75.00 \quad 53$

$\begin{array}{llllllllllll}0 & 0 & 0 & 0 & 1 & 1 & 1 & 1 & 1 & 1 & 0 & 0\end{array}$

1.3

$4 \quad 1.7 .30$

$41 \% .30$

4 1. 11.30

$4 \quad 1.13 .30$

$4 \quad 1.1 \% 3 . \%$

7 \% $7.2 \%$

$7 \% 9$

$\begin{array}{lllll}7 & 8 & 1 & 1 & .\end{array}$

$78013 . \%$

$78 \quad 19.8$

1.e. 197.46

1... 1.69 .46

1. 13 1. 11.46

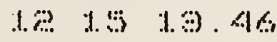

$12 \quad 1315.46$

coml...

Hile

mes

कि 


\section{DESCRIPTION OF THE MEASUREMENTS}

Interior daylight 11 luminance was measured in a rectangular test room with a north-facing window. A schematic drawing of the test room is shown in Figure 1. Illuminance on a horizontal plane was measured in the center of the room at a height of $76 \mathrm{~cm}(2.5 \mathrm{ft})$. The view out of the window from this point was nearly unobstructed, except for a few tree tops which obscured less than 10 percent of the sky view. Illuminance was measured using silicon photovoltalo cells with cosine diffusers and photometric filters. Concurrent measurements of solar radiation and 1 liumination levels were made for both diffuse (sky) and global (sky and sun) components, to provide the Input data necessary for the CEL-1 simulations. Data were collected over a six-month perlod to anable validation for a wide range of $\mathbf{s k y}$, solar and seasonal conditions. A complete description of test room dimensions and reflectances and window parameters is given in Table 2.

Table 2

Test Room Dimensions and Reflectances

Test Room

$\begin{array}{lll}\text { Width } & 1.6 \mathrm{~m} & (5.2 \mathrm{ft}) \\ \text { Height } & 2.1 \mathrm{~m} & (6.9 \mathrm{ft}) \\ \text { Depth } & 3.4 \mathrm{~m} & (11.2 \mathrm{ft})\end{array}$

Reflectances

\begin{tabular}{llll} 
Wall & \multicolumn{3}{c}{0.47} \\
Floor & 0.30 \\
Celling & \multicolumn{2}{c}{0.85} \\
& & & \\
Window - Double Pane & & \\
& & & \\
Width & $1.6 \mathrm{~m}$ & $(5.2 \mathrm{ft})$ \\
Helght & $0.9 \mathrm{~m}$ & $(2.8 \mathrm{ft})$ \\
Visible & Transmittance & 0.80
\end{tabular}


The validation results are presented in two formats. Figures 2 thru 6 each present a comparison of predicted versus measured illuminances for each of five days. In these figures, calculated interior ll luminances are plotted for each sky type, and the calculated il luminances for the sky types as chosen by CEL-1 are circled, and labeled with the atmospheric extinction coefficient as determined from measurement. Calculations were made for five times each day. Each measured interior illuminance consisted of a one-hour average, so the calculation used similarily averaged solar data. These five days include clear, partly cloudy, and overcast sky types from different times of the year. The days were chosen at random. From these figures it is seen that the CEL-1 predictions tend to follow the measured values closely, although some deviations are clearly evident. Figure 7 presents an overall comparison between the measurements and predictions.

A simple calculation of the standard deviation of the numbers formed by taking the ratio's of the CEL-1 predicted values to the corresponding measured values (or, alternatively, of the root-meansquare deviation of the ratio's from the constant model (unity) gives a $24 \%$ value. This can be thought of as representing a typical error of prediction. Expression in percent terms is preferred since the width of the error band clearly must increase with the magnitude of the prediction.

The levels of uncertainty described above are similar to the uncertainties stated for other similar illuminance prediction procedures, although validations of this type are rarely attempted. Most of the uncertainty is due to the random nature of real skies, which are rarely uniformly or predictably overcast or clear. Since any one window sees only a small portion of the sky, small variations in the luminance distribution of that portion of the sky can have a strong impact on interior illuminance, variations which would be too subtle for a computer model to predict using horizontal solar radiation as a driving function. This effect is illustrated in Figure 8, which presents a hemispherical photograph of a partly cloudy sky. From this figure it is obvious that daylight illumination due to the sky as seen through window $A$ would be significantly greater than that through window $B$, although both windows have nearly the same orientation.

Another uncertainty source is the determination of sky type. CEL-1 determines sky type on the basis of atmospheric extinction coefficient which is calculated from the level of direct beam illuminance. Thus, if no significant direct beam irradiance is incident, the sky is assumed to be overcast, and high direct beam irradiances are assumed to mean clear skies. These two assumptions are usually, but not always, valid. A single cloud could completely extinguish the direct beam solar radiation incident upon a surface, while the rest of the sky remained clear, or the sky could be nearly overcast except in front of the sun. Partly cloudy skies are particularly difficult to predict, due to their wide dynamic range. 
Taking into consideration the uncertainty associated with predicting interior daylight levels, it is still of value to use such techniques for evaluating fenestration performance. While one hundred percent accuracy is not possible, it is possible to compare the relative performance of various fenestration options as long as they are compared on a fair and equal basis.

Thus, it is most important that the simulation be realistic and reasonable even though the probabalistic aspects of sky modeling cannot be completely addressed. The validation figures demonstrate that the CEL-1 daylight II Iuminance predictions are reasonable for typical office spaces and realistic for the purpose of comparing fenestration options. 


\section{CONCLUSIONS}

Comparisons of predicted and measured interior illuminance levels were performed using the CEL-1 Lighting Computer Program and measurements made at the NBS Daylight Research. Faclilty. Results of the validation indicate a prediction uncertainty of $+1-24 \%$, an uncertainty level which is expected for this type of validation. The major sources of uncertainty are belleved to be associated with random and unpredictable cloud patterns. It is concluded that the CEL-1 simulation procedure would be of value in evaluating the daylighting performance of fenestration systems. 
6. REFERENCES

1. King, W.J., High Performance Solar Control Offlce Windors, Lawrence Berkeley Laboratory Report 7825, Berekely, CA, 1977.

2. Bitterice, M.G., McKinley, R.W., Use Solar Daylight and Heat from Windows to Save Foss11 Fuel, PPG Industries, Ino., 1978.

3. Owens, P.G.T., Energy Conservation and oresce Lighting, Pilkington Bros. Ltd., Technical Advisory Service, 1976.

4. Kusuda, T., Gillette, G., Treado, S.J., Eyaluation of The Daylighting and Energy Performance of Windows, Skylights,and Clerestories, National Bureau of Standards NBSIR 83-2726, June 1983.

5. Kusuda, T., Collins, B., Simplified Analysis of Thermal and Lighting Characteristics of Windows - Two Case Studies, National Bureau of Standards, Bullding Science Series 109, February 1978.

6. Johnson, R., Selkowitz, S., Hinkelman, F., Zenter, M., Glazing Optimization Study for Energy Efficiency in Commercial Office Buildings, Third International Symposium on Energy Conservation in the Built Environment, Dublin, Ireland, March 1982.

7. Jurovics, S., Daylight, Glazing and Building Energy Minimization, IBM Scientific Center publication, Los Angeles, CA., 1981.

8. Place, W., Fontoynant, M., Bauman, F., Anderson, B., Howard, T., Commerc1al Bullding Daylighting, LBLO-14348, Lawerence Berkeley Laboratory, Berkeley CA, 94720, 1982.

9. CEL-1 Lighting Computer Program - Programmer's Guide, CR83.009, Naval Civil Engineering Laboratory, Port Hueneme, CA, 93043, January 1983.

10. CEL,-1 Lighting Computer Program - User's Guide, CR81.026, Naval Civil Engineering Laboratory, Port Hueneme, CA, 93043, September 1981. 


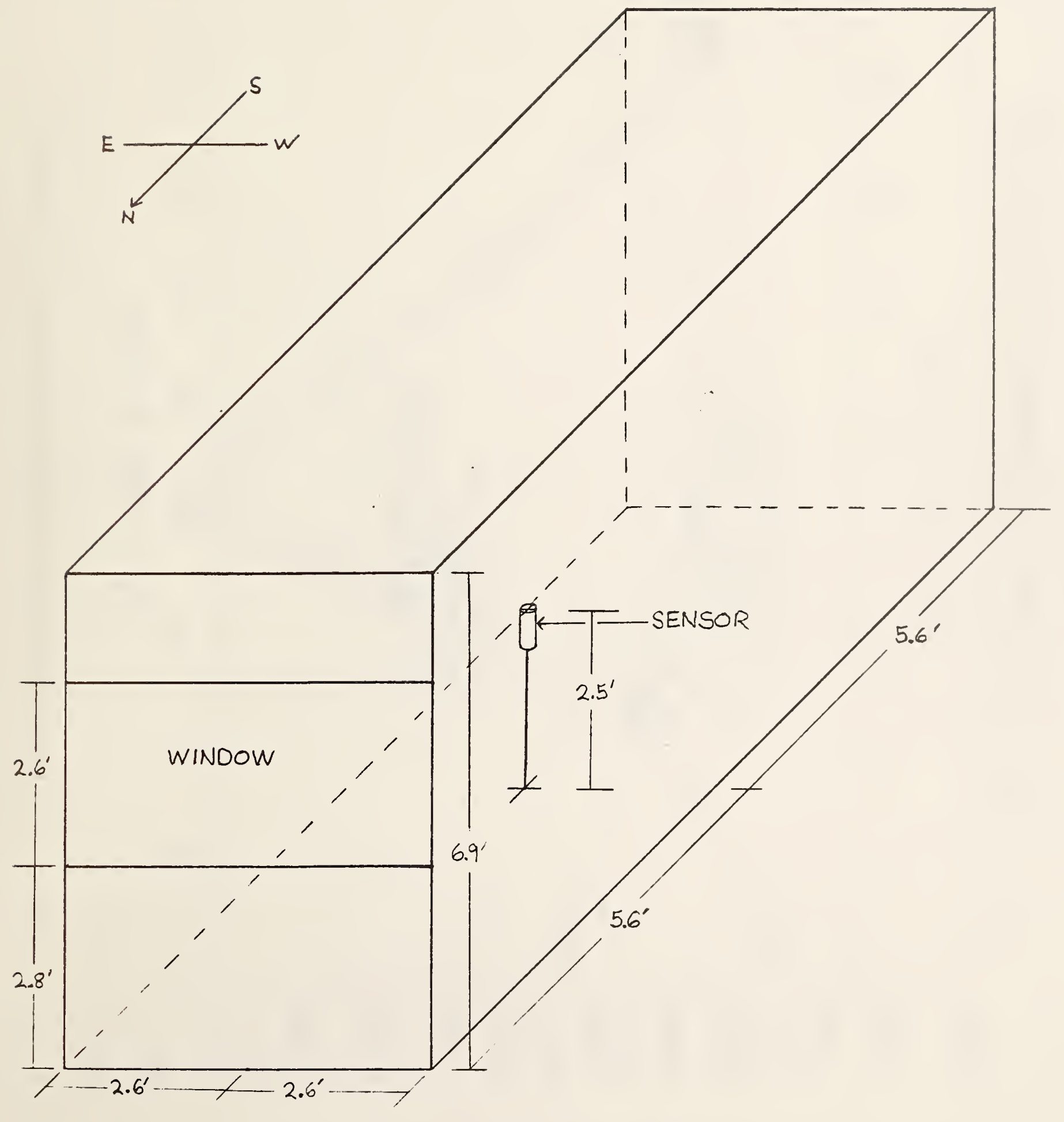

Figure 1. L,ayout of Test Room 


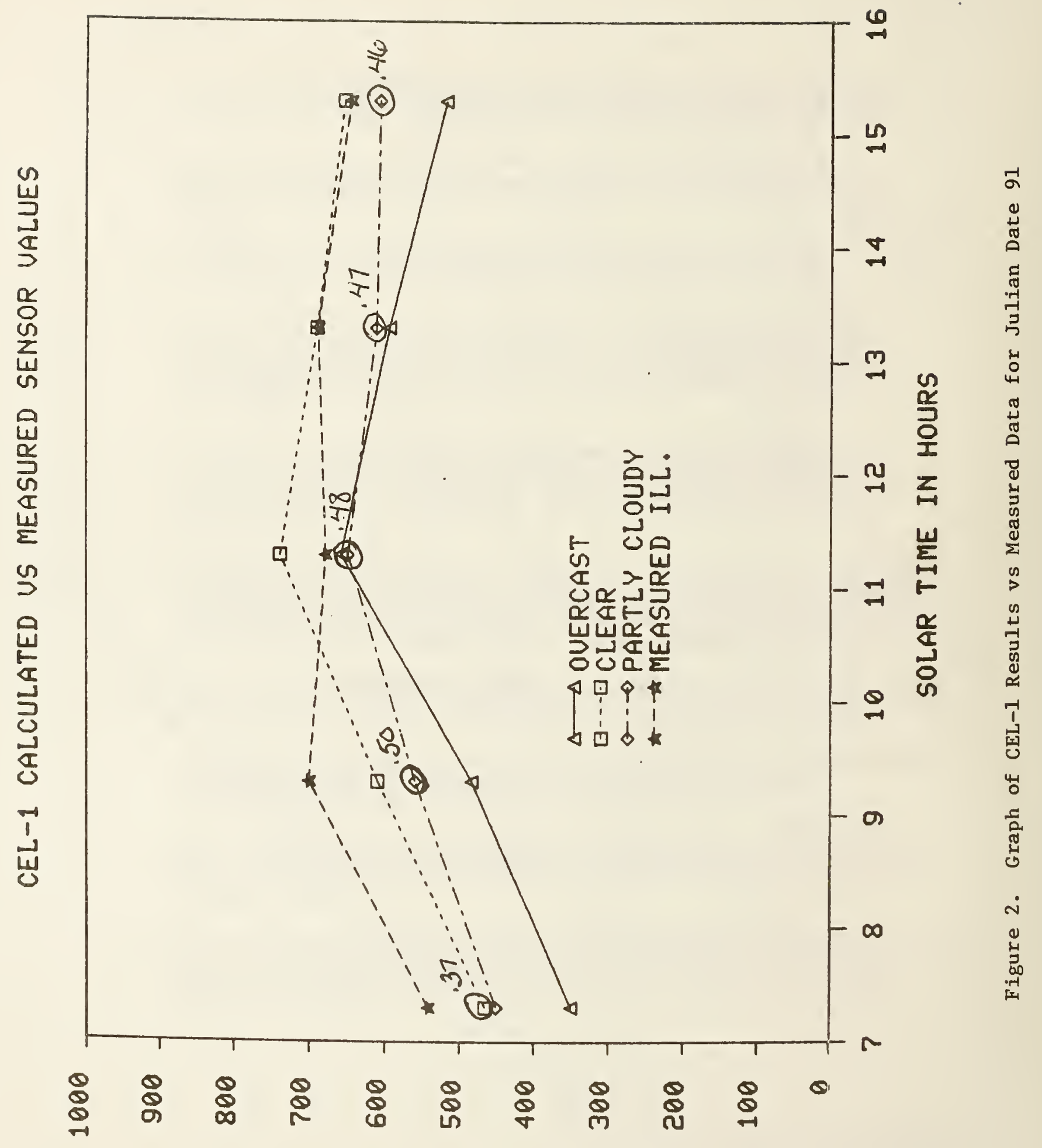

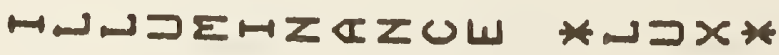




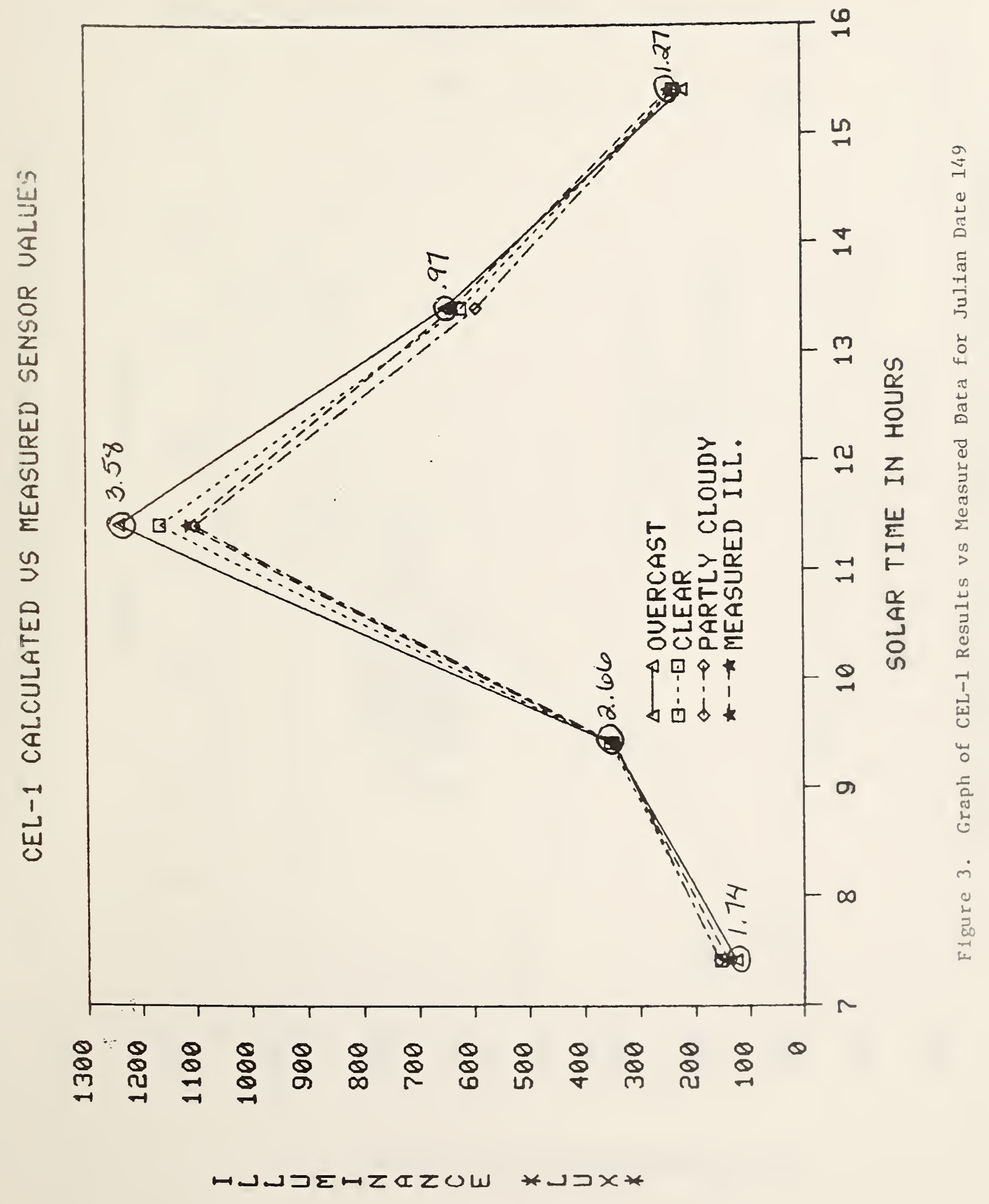




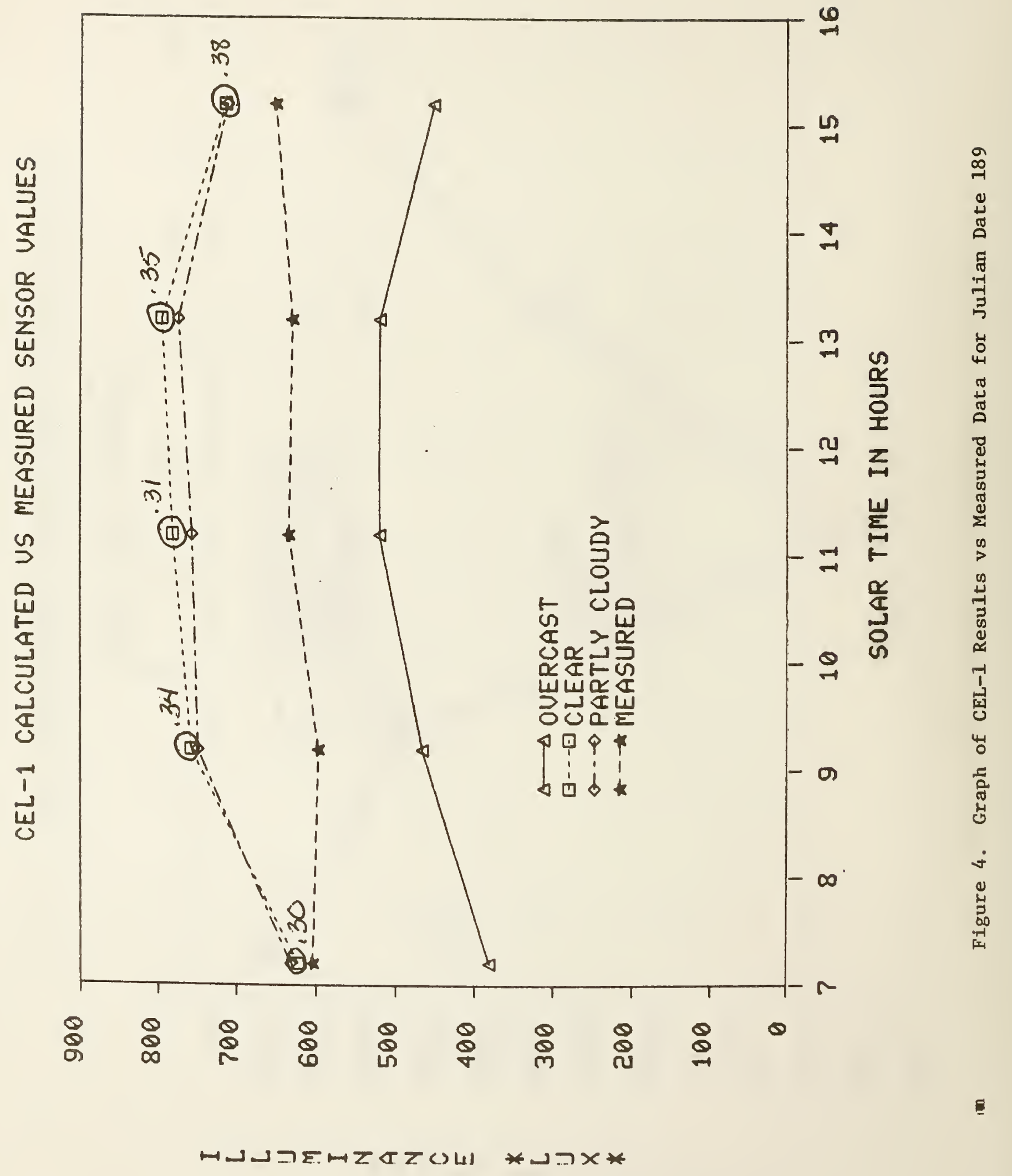




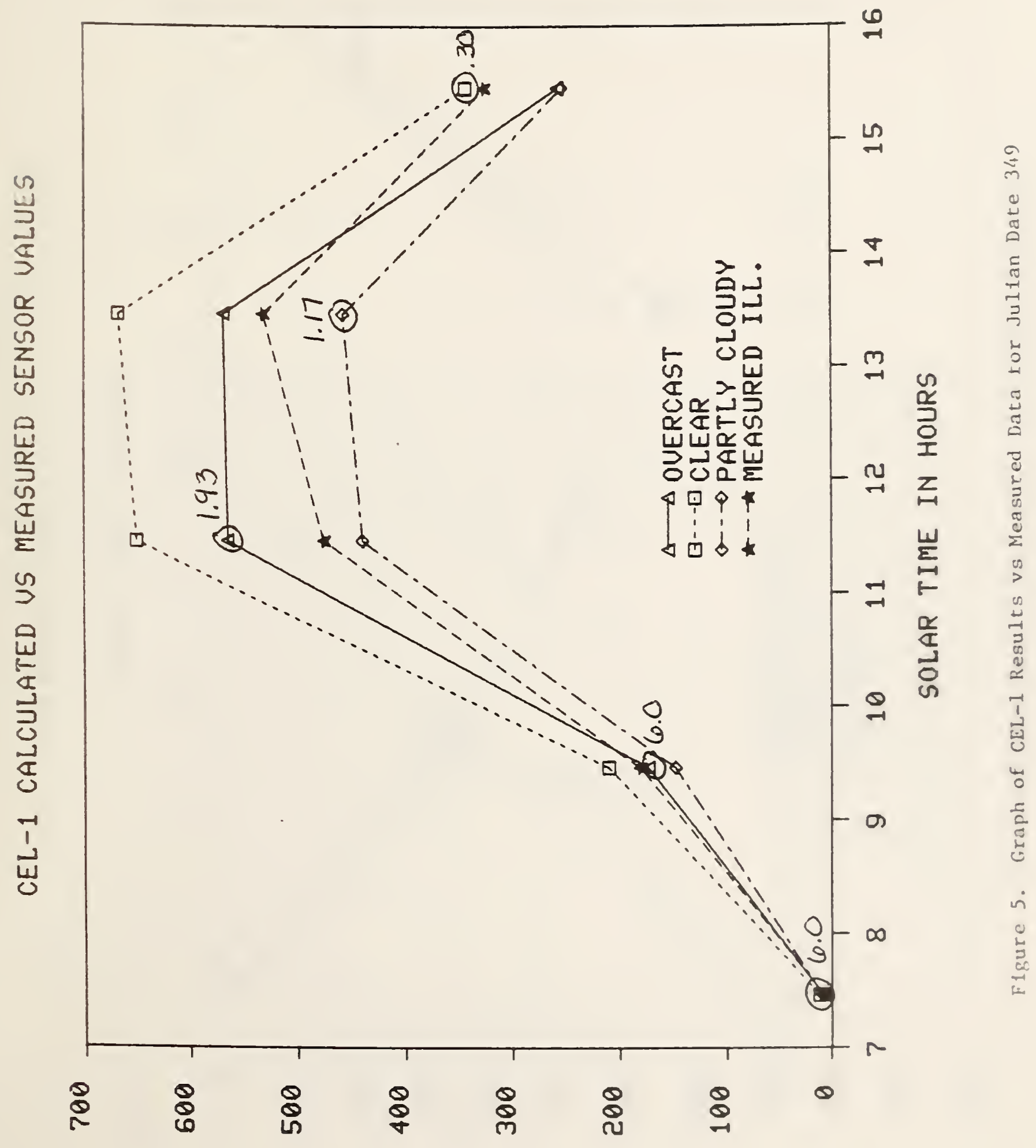

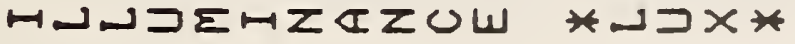




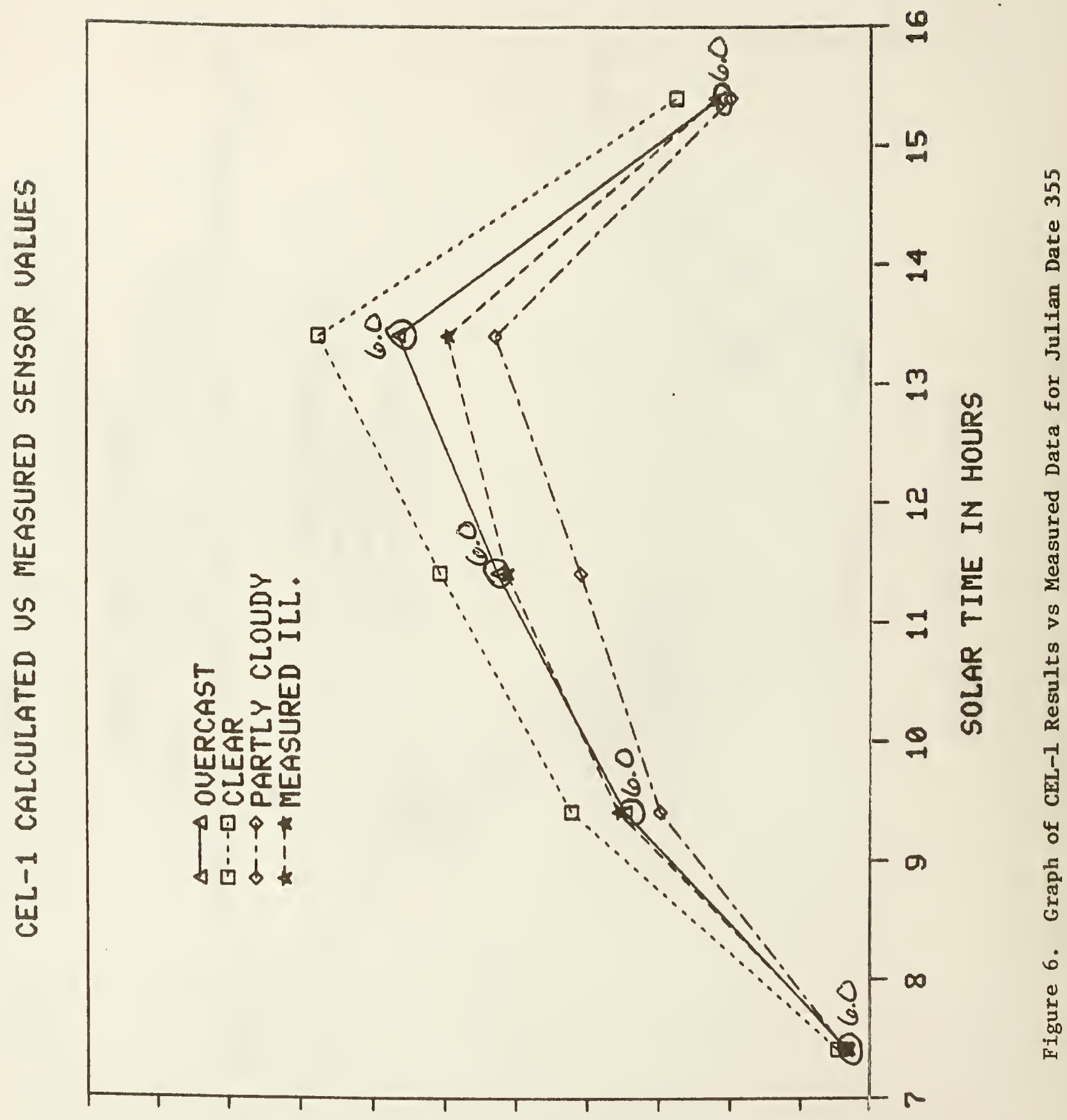

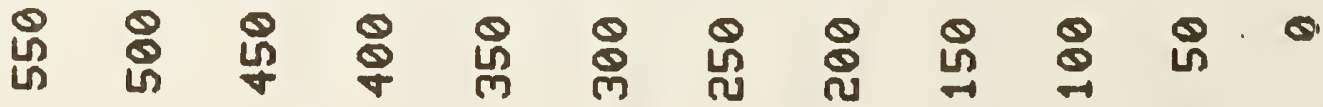




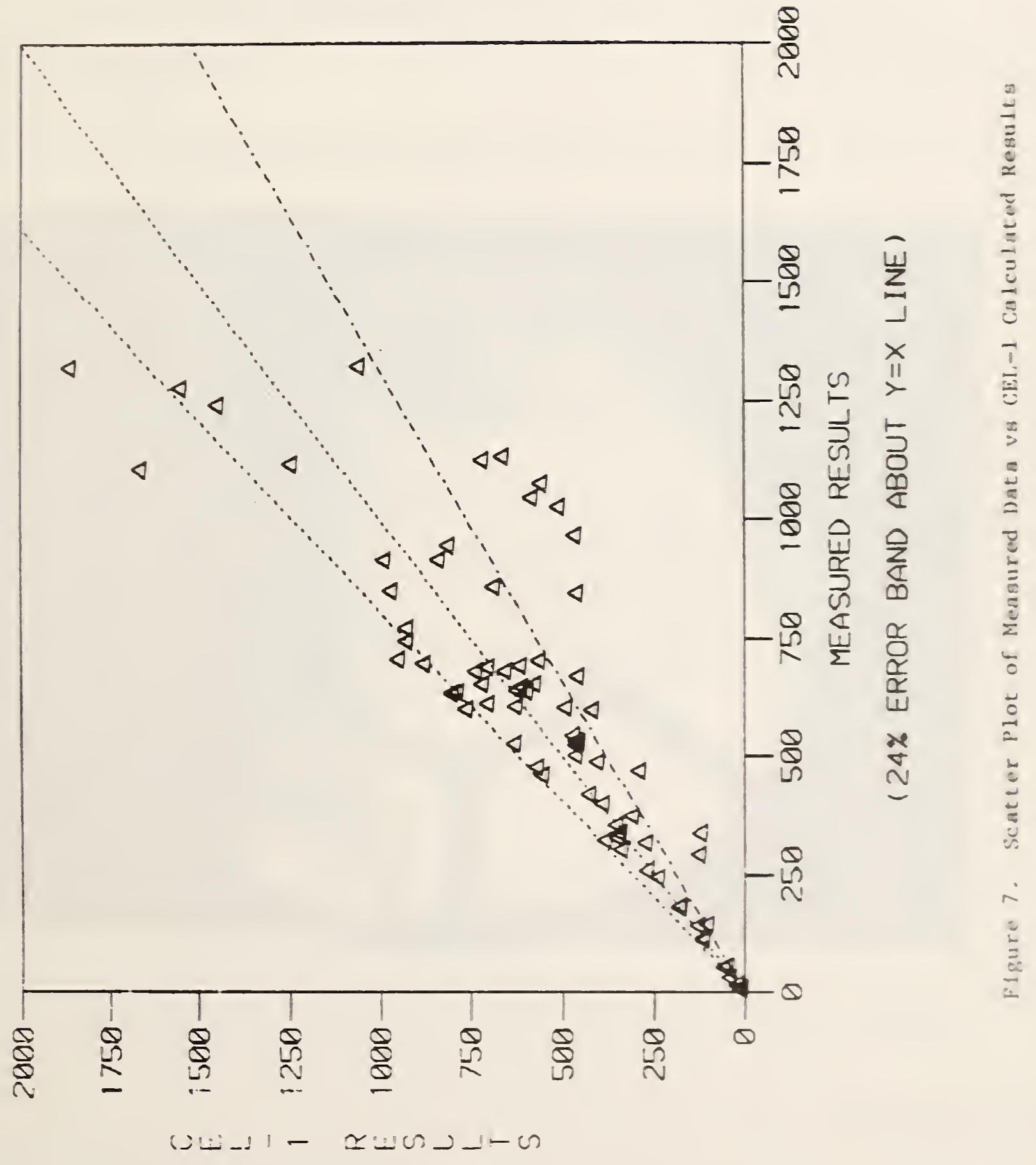




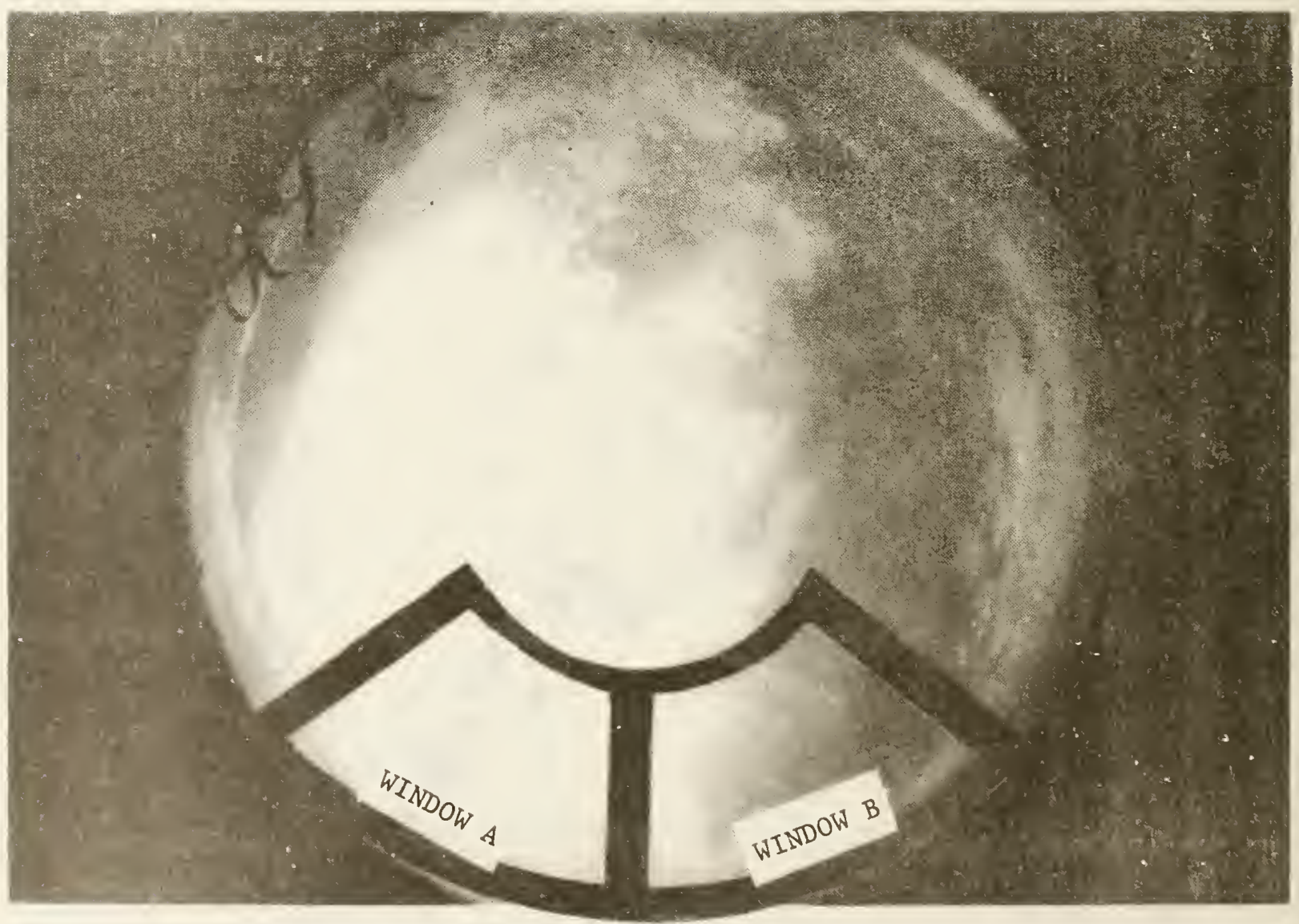

Figure 8. Effect of Sky Luminance Variations on Interior Illumination 16 
4. TITLE AND SUBTITLE

Validation of Daylight Prediction With CEL-1

\section{AUTHOR(S)}

Steve Treado, Cindy Francisco and Douglas Holland

6. PERFORMING ORGANIZATION (If joint or other than NBS, see instructions)

NATIONAL BUREAU OF STANDAROS

DEPARTMENT OF COMMERCE

WASHINGTON, D.C. 20234

9. SPONSORING ORGANIZATION NAME AND COMPLETE AODRESS (Street, City, State, ZIP)

7. Contract Grant No.

[ Document describes a computer program: SF-185, FIPS Software Summary, is attached.

11. ABSTRACT (A 200-word or less factual summary of most significont information. If document includes a significant bibliogrophy of literoture survey. mention it here)

Calculations of interior illuminance levels using the CEL-1 computer program are compared to measurements, for a typical office space. The comparisons are made for a wide range of sky conditions, solar intensities and seasonal intervals using a north facing window. The statistical uncertainty associated with the interfor daylight calculations is examined and the sources of the uncertainty are discussed. The results show that for all sky types, the interior illuminance calculations have an uncertainty of $+/-24 \%$, with the major uncertainties being due to unique and unpredictable sky luminance distributions and difficulty in determining the appropriate sky condition from standard weather data.

12. KEY WORDS (Six to twelve entries; alphabetical order: capitolize only proper names; and separote key words by semicolons) building energy, daylight, illuminance, fenestration, solar radiat1on, window

$\square$ Order From Superintendent of Documents, U.S. Government Printing Office, Washington, D.C. 20402.

14. NO. OF PRINTED PAGES Order From National Technical Information Service (NTIS), Springfield, VA. 2216I

$\begin{array}{r}23 \\ \text { 15. Price } \\ 67.07 \\ \hline\end{array}$




